Doctor Libardo Meléndez

Prof. Asistente Medicina Interna, Universidad Javeriana.

Doctor Gustavo Salas

Instructor Medicina Interna

Doctor Antonio Acevedo

Presidente Medicina Interna

Bogotá, D. E. - Colombia

Urología M. G. En 17 pacientes con infecciones urinarias se obtuvieron ocho resultados excelentes $y$ seis buenos. $\mathrm{Ni}$ reacciones alérgicas ni efectos colaterales importantes.

\title{
BACTRIM 'Roche' EN INFECCIONES DE LAS VIAS URINARIAS
}

\author{
Univérsitas Médica - Vol. XIII - № 1, 1971
}

La gran incidencia de enfermedades infecciosas de las vías urinarias y el encuentro repetido de resistencia bacteriana al tratamiento, indujeron a los autores de este trabajo a estudiar la eficacia de la asociación de Sulfametoxazol y Trimetoprim (BACTRIM 'Roche') en pacientes con pielonefritis aguda de los Hospitales San Ignacio de Bogotá y San Rafael de Tunja.

En el capítulo titulado "DISCUSION" encontramos estas apreciaciones que transcribimos a continuación:

El médico cuenta en la actualidad con numerosas preparaciones antimicrobianas eficaces en el tratamiento de las infecciones urinarias agudaș o crónicas. Sin embargo, diariamente se observa la aparición de cepas resistentes; por esta razón, el advenimiento de nuevos preparados antibacterianos siempre es recibido con interés. Nuestro estudio está de acuerdo con numerosos reportes recientes de la literatura mundial (1-5) sobre la eficacia de la asociación de sulfametoxazol y trimetoprim en infecciones urinarias y en otro tipo de infecciones. Cada una de estas drogas tiene una acción bacteriostática reconocida; sin embargo, la asociación de las dos no resulta solamente en el efecto aditivo de sus propiedades bacteriostáticas, sino que ha sido demostrado que su administración conjunta en proporciones adecuadas, como las que se encuentran en el preparado BACTRIM 'Roche', resulta en una potenciación de sus efectos cuya resultante es una acción bactericida. El mecanismo de acción de la combinación es de interés: se encuentra en el bloqueo simultáneo de dos reacciones enzimáticas en una misma cadena de reacciones del metabolismo bacteriano: al bloquearse los efectos de la sintetasa y la reductasa del ácido dihidrofólico se impide la producción de DNA y de RNA en la bacteria, al quedar inhibida la síntesis de purinas. La potenciación se ha demostrado "in vitro" (6) e "in vivo" (7).

En esta comunicación se presenta un estudio que incluye un grupo de 17 pacientes con pielonefritis, compuesto por 5 hombres y 12 mujeres, con edades de 13 a 71 años, promediando 44. Antes de iniciar los tratamientos

* Marca Registrada. 
con BACTRIM 'Roche' se efectuaron exámenes clínicos completos y análisis de laboratorio consistentes en cuadro hemático, examen de orina, urocultivo, recuento de colonias y antibiogramas. Se identificaron como gérmenes infectantes E. Coli, Estafilococo y Proteus. Las conclusiones se comunican como sigue:

\section{RESUMEN}

El efecto antimicrobiano de la asociación de sulfametoxazol y trimetoprim (BACTRIM 'Roche') fue estudiado en 17 pacientes con infecciones de vías urinarias. Se encontró que la asociación en la proporción presentada en el producto BACTRIM 'Roche', fue de resultados excelentes en ocho de los casos, buenos en seis e insatisfactorios en tres. Dos de los tres casos con respuesta insatisfactoria fueron pacientes con uropatía obstructiva crónica. No se encontraron reacciones alérgicas ni efectos colaterales importantes, diferentes de molestia gástrica. Nuestro estudio permite concluir que el preparado BACTRIM 'Roche', con $80 \mathrm{mg}$. de Trimetoprim y $400 \mathrm{mg}$. de Sulfametoxazol por comprimido, en dosis de dos comprimidos cada doce horas y por un mínimo de cinco días es una forma eficaz de tratamiento de infecciones de vías urinarias. Los autores recomiendan sin embargo constatar la mejoría ocuración del estado infeccioso mediante estudios bacteriológicos apropiados. En casos crónicos o recidivantes estos estudios deberán repetirse periódicamente.

\section{BIBLIOGRAFIA}

1 REEVES, D. D. et al, Trimethoprim-Sulphamethoxazole: Comparative Study in Urinary Infection in Hospital. Brit. Med. J. 1: 541, 1969.

2 SOURANDER, L. B. \& WERNER, G. E.: Efficacy and tolerance of Sulphonamide-Trimethoprim Combinations in Geriatric Patients with Bacteriuria. Procedings of the 5th International Congress of Chemotherapy, Col. V. pp. 199-211.

3 WILLIAMS, J. D. \& BRUMFITT W. Trimethoprim-Sulphonamide combinations in the treatment of Bacteriuria of Pregnancy. The Synergy of Trimethoprim and Sulphonamides. Procedings of the Royal College of Physicians, 9.5, 1969.

4 BERNSTEIN-HAHN, L. Chemotherapy in Chronic Urinary Tract Infection. Annual Meeting on Paraplegia, Tel-Aviv, 3.11, 1968.

5 BUSHBY, S. R. M. \& HISCHINGS, G. H. Trimethoprim, a Sulphonamide Potentiation Brit. J. Pharmacol. 33: 72, 1968.

6 BOHNI, E. Trimethoprim-Sulphamethoxazole in vitro and in vivo. Chemotherapy 14, Supl., 1969.

7 Trimethoprim in the Urinary Tract. Brit. Med. J. 1: 525, 1969. 